\title{
Assessment of antimicrobial and immunomodulatory activities of termite associated fungi, Termitomyces clypeatus R. Heim (Lyophyllaceae, Basidiomycota)
}

Oumar Mahamat ${ }^{1 *}$, Njouonkou André-Ledoux ${ }^{1}$ Tume Chrisopher ${ }^{2}$, Abamukong Adeline Mbifu ${ }^{1}$ and Kamanyi Albert ${ }^{3}$

\begin{abstract}
Background: Termitomyces clypeatus (T. clypeatus) is an edible mushroom specie which grows in various areas in Cameroon. It is indicated by several healers in treatment of several infectionsand is frequently used for this purpose. However, no study has been reported on its antibacterial and immunomodulatory activities which were the aim of this study.

Methods: Disc diffusion method was used to appreciate the bactericidal activity against 4 bacteria and 2 yeast species. The immunomodulatory activities were assessed in mice, where the extract was administered by gavage and as supplement in the feed. The treatment was done for 10 days. Delayed type hypersensitivity test was carried out to assess the cell mediated immune response while the effect on humoral immunity was evaluated using hemagglutination assay and mice lethality test.. The body weight was also recorded in mice used for delayed hypersensitivity.
\end{abstract}

Results: It was found that extract of T. clypeatus highly inhibited the growth of bacteria and yeast at different ratios compared to the medium $(P<0.05)$. The extract of $T$. clypeatus has reversed the immunosuppressed effects of dexamethasone on antibody formation. In addition, it significantly decreased of the mice lethality rate in mice infected by Pasteurella multocida $(P<0.05)$. Administration of $T$. clypeatus also significantly increased the delayed type hypersensitivity response in healthy and dexamethasone immunosuppressed mice $(P<0.05)$, but it significantly reduced the body weight of mice after 10 days.

Conclusion: The results provided basic information demonstrating the antibacterial activity and immunostimulatory activity of $T$. clypeatus on both cell-mediated and humoral immunity.

Keywords: Cell-mediated immunity, Humoral immunity, Immunomodulation, Antibacterial, Termitomyces clypeatus

\section{Background}

Use of natural products as an alternative to conventional treatment for various diseases has been on the rise in the last few decades [1]. In public concern about dietary and health issues, the increase in the consumption of fungal food have been reported on a global basis [2]. Besides nutritional value which have industrial applications, many species of Termitomyces are cited to possess

\footnotetext{
*Correspondence: oumahamat@yahoo.com

${ }^{1}$ Department of Biological Sciences, Faculty of Science, University of

Bamenda, PO. Box: 39, Bambili, Cameroon

Full list of author information is available at the end of the article
}

medicinal properties $[2,3]$. In the last few decades, research has been focused on antibacterial, antifungal effects of mushroom. Nosocomial agents such as; Escherichia coli, Pseudomonas aeruginosa, Enterococcus spp., Streptococcus spp., Candida albicans, and Enterobacter cloacae have long been designated as the most frequent microorganisms causing bacteremia and fungemia [4]. Thus, various studies are focused to the use of plants or mushrooms as therapeutic agents against these agents. In addition, the effects on the immune system as the most therapeutic effects of 
medicinal plants in the treatment of infectious diseases have been demonstrated $[5,6]$.

Mushrooms have been used extensively in traditional medicine throughout the world. Several species, have been identified as potent immunomodulators or bactericide and they are used to treat infections [6, 7]. In several studies it was demonstrated that mushrooms of the genus Termitomyces possess the immunomodulatory or antibacterial activities [7]. Termitomyces clypeatus R. Heim is among the most common popular edible and medicinal mushrooms in many tropical countries including Brazil, India, Philippine and Cameroon [8-11]. It is recommended by the traditional healers to treat some gastrointestinal infectious diseases. However, no study was done to exhibit its pharmacological properties.

In the present study, Termitomyces clypeatus was tested for its immunomodulatory and antimicrobial activities.

\section{Methods \\ Materials \\ Collection of specimen and preparation of extract}

Fresh samples of Termitomyces clypeatus were bought in local markets of the North-West and West regions of Cameroon. The specimen was authenticated thanks to the laboratory investigation of their macroscopical and microscopical characteristics in the Laboratory of Biological Sciences of The University of Bamenda. The samples were washed and cut into small pieces. Then, they were dried at the oven for 3 days at $35{ }^{\circ} \mathrm{C}$. The dried samples were ground to obtain a fine powder of the mushroom. The powder, $100 \mathrm{~g}$ was dissolved in $500 \mathrm{ml}$ distilled water and boiled for $20 \mathrm{~min}$. The solution was filtered using Watman paper $\mathrm{N}^{\circ} 1$. The filtrate was evaporated in the oven at $35^{\circ} \mathrm{C}$ and the dried product constituting the aqueous extract (AEM) used for the research work.

\section{Animals}

Adult healthy Swiss albino mice (Mus musculus) of both sex and having 10-12 weeks old and 17-19 g body weight were used in his study. They were raised at the animal house of the department of Biological Sciences, University of Bamenda, where the study was conducted. The colony was obtained from the National Veterinary Laboratory (LANAVET), Garoua, Cameroon. The experiments were conducted under conditions of temperature and light (Light:dark, $12 \mathrm{h:}: 12 \mathrm{~h}, \mathrm{~T}^{\circ} \mathrm{C}, 25 \pm 2{ }^{\circ} \mathrm{C}$ ). The animals were fed with a standard mouse feed procured from LANAVET and water ad libitum.

\section{Red blood cells}

Fresh cow red blood cells (CRBC) were obtained from cow's blood as described by Heden (1946) [12] and used as antigen [13]. Briefly, veinous blood was collected from cow in EDTA-tubes and kept in the laboratory for $15 \mathrm{~min}$. The plasma was therefore discarded and pellet (red blood cells) was washed three times in a large volume of pyrogen-free sterile normal saline by repeated centrifugation at $2500 \mathrm{rev} / \mathrm{s}$ for $10 \mathrm{~min}$ on each occasion. The washed CRBC was adjusted to a concentration of approximately $1 \times 10^{9}$ cells $/ \mathrm{ml}$ and used for both immunization and challenge.

\section{Test microorganisms}

Five (5) strains of 5 bacteria (Pasteurella multocida NCTC 12178, methicillin-sensitive Staphylococcus aureus MSSA, Escherichia coli ATCC 25922, Enterobacter aerogenes ATCC 13048 and Salmonella typhi Ty2 ATCC 700931) and 2 yeast (Candida albicans ATCC10231 and Candida glabrata ATCC 66032 were used in this study. Microorganisms were provided by the Biochemistry Research Laboratory, Department of Biochemistry, Faculty of Science, University of Dschang-Cameroon.

\section{Experimental design \\ Evaluation of antimicrobial activity}

The AEM was subjected to antibacterial assay using the agar diffusion plate method as described by Alves and colleagues (2000), with some changes and guided by NCCLS/CLSI (2005) [6, 7]. Tests were carried out using $100 \mu \mathrm{l}$ of suspension containing $10^{8} \mathrm{per} / \mathrm{ml}$ of bacteria (S. aureus, E. coli, E. aerogenes and S. typhi) and $10^{4}$ per/ $\mathrm{ml}$ yeast (C. albicans and C. glabrata). Bacteria were inoculated into veal Broth (Difco) containing agar (1\%) while yeasts were inoculated into malt extract gar (Difco). Petri dishes were prepared at $4{ }^{\circ} \mathrm{C}$ for 10 to $20 \mathrm{~min}$. Then, four wells (6 mm diameter) were made and aseptically filled up with $100 \mu \mathrm{l}$ of the extract at different concentrations $(125,250$ and $500 \mu \mathrm{g} / \mathrm{ml})$. Nystatin and Streptomysin sulfate $(100 \mu \mathrm{g} / \mathrm{ml})$ were used as positive control whereas Mueller-Hinton agar only was used as negative control for microbial growth. Then, the inoculated plates were incubated at $25^{\circ} \mathrm{C}$ for $48 \mathrm{~h}$ for yeast and $37 \pm{ }^{\circ} \mathrm{C}$ for $24 \mathrm{~h}$ for bacterial strains. At the end of the incubation period, the diameter $(\mathrm{mm})$ of clear zone considered as growth inhibition was measured. [14, 15]

\section{Animal grouping}

To assess the humoral and delayed type hypersensitivity (DTH) response, white mice weighing 15-19 g were divided into 2 groups: group 1 (animal not treated) and group 2 (treated with dexamethasone). Each group of mice was randomly shared into 4 subgroups of 5 animals each. Dexamethasone sodium, an immunosuppressing agent was intramuscularly administered at the rate of $5 \mathrm{mg} / \mathrm{kg}$ every day for 7 days. The first subgroup (subgroup 1) of each group or control subgroup was fed with 
distilled water. The second subgroup (subgroup 2) of each group taken as positive control was received levamisole hydrochloride subcutaneously at the rate of $2.5 \mathrm{mg} / \mathrm{kg}$ thrice a week. The other subgroups (3 and 4) of each category were taken as subgroups tests and were daily fed with the extract (AEM) at the rate of $500 \mathrm{mg} /$ $\mathrm{kg}$ and $1000 \mathrm{mg} / \mathrm{kg}$ by gavage. The test groups were also fed with feed supplemented with the powder of mushroom at 25 and $50 \%$ respectively for animal receiving 500 and animal receiving $1000 \mathrm{mg} / \mathrm{kg}$. The Table 1 shows the animal grouping. This study was approved by Institutional Animal Ethical Committee.

\section{Delayed type hypersensitivity response}

Twenty mice were grouped as described above. The two test groups were daily fed with extract and powder of the mushroom for 10 days. Delayed type hypersensitivity (DTH) was assessed by evaluating the sensitivity to CRBC. On day 5 of the treatment, $0.2 \mathrm{ml}$ of $1 \times 10^{9}$ cells/ml CRBC was administered subcutaneously in the plantar region of the right hind foot paw. Then, animals were challenged on day 10 by a second subcutaneous injection of the same amount of antigen into the left hind paw. The edema produced by antigenic challenge in the left hind paw was taken as the difference in the paw thickness before and $30 \mathrm{~min}, 24 \mathrm{~h}$ and $48 \mathrm{~h}$ after the challenge. The paw thickness was measured by volume displacement. Body weight of the animals was recorded before and on day of the challenge.

\section{Humoral antibody response}

Twenty mice were randomized and treated for 10 days as above. Then, they were immunized by an intraperitoneal injection (i.p.) of $0.2 \mathrm{ml}$ of $1 \times 10^{9} \mathrm{CRBC} / \mathrm{ml}$ at the first day. In a late 5 days of treatment, the mice were challenged by injecting the same of CRBC. On day 11, animals were slaughtered and the blood samples were collected by cardiac puncture for analysis of serum. Antibody titer was determined by the haemagglutination technique [13]. Briefly, $25 \mu \mathrm{l}$ of serum was put in

Table 1 Animal grouping following the treatment

\begin{tabular}{lll}
\hline Groups & Subgroups & Treatments \\
\hline Group I & 1 & Control \\
& 2 & Levamisole \\
& 3 & AEM $500 \mathrm{mg} / \mathrm{kg}$ \\
& 4 & AEM $1000 \mathrm{mg} / \mathrm{kg}$ \\
Group II & 1 & Dexamethasone \\
& 2 & Dexamethasone + Levamisole \\
& 3 & Dexamethasone + AEM $500 \mathrm{mg} / \mathrm{kg}$ \\
& 4 & Dexamethasone + AEM $1000 \mathrm{mg} / \mathrm{kg}$ \\
\hline
\end{tabular}

Group I is constituted of normal mice

Group II is constituted of mice treated with dexamethasone
96 U-bottom microtitre plates and serially diluted two-fold using pyrogen free sterile normal saline. The last well on each row contained sterile normal saline was considered as control. The diluted sera were challenged with $25 \mu \mathrm{l}$ of $1 \%(v / \mathrm{v}) \mathrm{CRBC}$ and incubated at $37{ }^{\circ} \mathrm{C}$ for $1 \mathrm{~h}$. The highest dilution giving rise to visible haemagglutination was taken as antibody titer. The experiment was done in three replicates.

\section{Mice lethality test}

Thirty mice were divided into 5 groups of 6 animals. The first group was taken as control and was kept uninfected. Group 2 was taken as negative control and was infected and received distilled water. Group 3, taken as positive control, was infected and treated by levamisole. Groups 4 and 5 were taken as test groups and they were infected and fed with the extract at the dose of 500 and $1000 \mathrm{mg} / \mathrm{kg}$ respectively as described above. The extract was daily administered for 15 days starting from day 1 . All the animals were immunized through intraperitoneal route with hemorrhagic septicemia vaccine, except negative control on 5th and 10th day of the treatment., Mice were subcutaneously challenged with $P$. multocida on 15 days of treatment and examined for about $72 \mathrm{~h} . P$. multocida were injected at the $\mathrm{LD}_{50}$ of $10^{5}$ cells in $0.5 \mathrm{ml}$ of normal saline.

\section{Statistical analysis}

Values are expressed as Mean \pm SD. Results obtained were statistically analyzed by using one-way ANOVA followed by tukey-krammer multiple comparison test. $P<0.05$ was considered a significant value.

\section{Results}

\section{Antimicrobial activity}

The results on the antimicrobial activities of $T$. clypeatus tested in vitro against some bacteria and fungi are presented in Table 2 below. The extract of $T$. clypeatus showed a significant activity against $E$. coli, E. aerogenes, S. aureus, S. typhi, C. albican and C. glabrata compared to the control or simple medium. The inhibition zone was different for the various microbial strains. It was as follow: $E$. coli (2.6 to $6.6 \mathrm{~mm}), E$. aerogenes (1.8 to $2.8 \mathrm{~mm}$ ), S. aureus (55 to $10.5 \mathrm{~mm}$ ), S. typhi (0 to $5.5 \mathrm{~mm}$ ), C. albicans (3.9 to $8.5 \mathrm{~mm}$ ) and C. glabrata (2.9 to $10.0 \mathrm{~mm}$ ).

\section{Effect on humoral response}

Agglutination test was used to measure the level of antibodies to particulate CRBC. Serum from normal mice receiving the different doses of AEM has not shown significant haemagglutination titer compared to the control. While, the potentiation of humoral response by standard immunomodulatory drug levamisole has resulted in higher 
Table 2 Antimicrobial activity of T. clypeatus against some bacteria and yeast species

\begin{tabular}{|c|c|c|c|c|c|c|}
\hline Microbes Extract Conc. ( $\mu \mathrm{g} / \mathrm{ml})$ & E. coli & E. aerogenes & S. aureus & S. typhi & C. albicans & C. glabrata \\
\hline -ve control & $-{ }^{a}$ & $-{ }^{a}$ & $-{ }^{a}$ & $-^{a}$ & $-^{a}$ & $-{ }^{a}$ \\
\hline 125 & $2.6 \pm 0.7^{b}$ & $1.8 \pm 0.3^{b}$ & $5.5 \pm 0.8^{b}$ & $-{ }_{-}^{a}$ & $3.9 \pm 0.7^{b}$ & $2.9 \pm 1.8^{b}$ \\
\hline 250 & $4.8 \pm 1.7 b^{c}$ & $2.5 \pm 0.3 b^{c}$ & $8.5 \pm 1.1^{c d}$ & $2.7 \pm 0.8^{b}$ & $6.5 \pm 0.8^{c}$ & $6.9 \pm 0.7^{c}$ \\
\hline 500 & $6.6 \pm 1.2^{c}$ & $2.8 \pm 0.9^{c}$ & $10.5 \pm 0.7^{d}$ & $5.5 \pm 1.2^{c}$ & $8.5 \pm 0.7^{d}$ & $10.0 \pm 1.4^{d}$ \\
\hline +ve Control & $13.0 \pm 0.1^{\circ \circ}$ & $14.0 \pm 0.0^{\circ \circ}$ & $17.0 \pm 0.1^{\circ \circ}$ & $16.0 \pm 0.1^{\circ \circ}$ & $16.5 \pm 0.5^{\circ}$ & $13.2 \pm 0.5^{\circ}$ \\
\hline
\end{tabular}

-ve control indicates medium only while +ve control indicate the antibiotics which were Nystatin and Streptomysin sulfate: $100 \mu \mathrm{g}$. Comparison antibiotic: ${ }^{\circ} \mathrm{Nystatin},{ }^{\circ}$ Streptomysin sulfate. The symbol (-) indicate that no inhibition was detected. Each value is the mean \pm SD of three replicates. Values with different small letters in the same column are significantly different at the level of $0.05(P<0.05)$

antibody titer. In the category II of dexamethasone-treated groups, serum from mice receiving the doses of AEM showed a high haemagglutination titer as compared to dexamethasone group (Table 3).

\section{Effect on the mortality rate in mice lethality test}

Administration of $P$. multocida caused $100 \%$ mortality in $48 \mathrm{~h}$ in the negative control group, whereas 33.33\% mortality was observed in positive control group within $72 \mathrm{~h}$. Treatment with AEM500 and AEM1000 mg/kg caused the mortality rate of 50 and $33.33 \%$, respectively as compared with positive control group. We observed the death of one mouse after $24 \mathrm{~h}$ and two mice later after $72 \mathrm{~h}$ in low dose treated group. In AEM1000 mg/kg treated group, we found one mouse dead with $48 \mathrm{~h}$. Subsequently, one mouse died after $72 \mathrm{~h}$. Treatment with $2.5 \mathrm{mg} / \mathrm{kg}$ of levamisole caused $40 \%$ mortality after $24 \mathrm{~h}$ (Table 4).

\section{Effect on cell mediated immunity in normal mice}

Cow red blood cells (CRBC) induced DTH reaction was used to study the effect of the extract on cell mediated immunity in normal mice. Pretreatment of the AEM and consumption of the mushroom powder has shown significant increase in paw thickness $(p<0.01)$ after $30 \mathrm{~min}$, 24 and $48 \mathrm{~h}$ of challenge at the doses of 500 and $1000 \mathrm{mg} / \mathrm{kg}$ of extract (Fig. 1). The increase delayed type hypersensitivity response has observed at $30 \mathrm{~min}, 24$ and

Table 3 Effect of the treatment by T. clypeatus on haemagglutination titer level in mice

\begin{tabular}{|c|c|c|c|c|}
\hline Groups & Subgroups & Treatment & & Titer level \\
\hline \multirow[t]{4}{*}{ Group I } & 1 & - & Distilled water & $36 \pm 20,13^{a}$ \\
\hline & 2 & - & Levamisole & $224 \pm 192^{c}$ \\
\hline & 3 & - & AEM500 mg/kg & $44 \pm 24^{a}$ \\
\hline & 4 & - & AEM1000 mg/kg & $48 \pm 18,47^{a}$ \\
\hline \multirow[t]{4}{*}{ Group II } & 1 & Dexamethasone & Distilled water & $6 \pm 2,3^{\mathrm{a}}$ \\
\hline & 2 & Dexamethasone & Levamisole & $40 \pm 16^{b}$ \\
\hline & 3 & Dexamethasone & AEM500 mg/kg & $32 \pm 22,62^{b}$ \\
\hline & 4 & Dexamethasone & AEM1000 mg/kg & $37,33 \pm 24,44^{b}$ \\
\hline
\end{tabular}

Data represent the Means \pm SD $(n=5)$. Values with different small letters in the same category are significantly different at the level of $0.05(P<0.05)$
$48 \mathrm{~h}$ after the antigenic challenge. Standard immunostimulant, levamisole, has also induced a significant increase in DTH response compared to control after $30 \mathrm{~min}$ and $24 \mathrm{~h}$.

\section{Effect on cell mediated immunity in dexamethasone treated mice}

Potentiation of DTH response was also observed in Dexamethasone treated mice compared to untreated Dexamethasone treated mice. Increase in paw edema after challenge was observed in all extract treated groups similar to the standard, levamisole, when compared to negative control (dexamethasone treated group) (Fig. 2). Levamisole and mushroom treatment (AEM 500 and $1000 \mathrm{mg} / \mathrm{kg}$ ) have shown mild increase in DTH response compared to control (dexamethasone untreated group). The increase in DTH response has observed in extract treated mice after $30 \mathrm{~min}$ and response has subsided up to $48 \mathrm{~h}$.

\section{Effect of T. clypeatus extract on mice's body weight}

Body weights of mice in different groups showed a decrease in body's weight of mice after the period of the study in treated mice (Table 5). The capacity of T. clypeatus to reduce the weight of mice has observed in normal mice and dexamethasone treated mice. In contrast, mice in the control groups have significant increase in body's weight $(P<0.05)$.

Table 4 Mice lethality rate at 24, 48 and $72 \mathrm{~h}$

\begin{tabular}{lllll}
\hline Groups & After $24 \mathrm{~h}$ & After $48 \mathrm{~h}$ & After $72 \mathrm{~h}$ & Total lethality (\%) \\
\hline Untreated control & - & - & - & - \\
Negative control & 33.33 & 66.66 & - & 100 \\
Positive control & - & - & 33.33 & 33.33 \\
AEM $500 \mathrm{mg} / \mathrm{kg}$ & 16.66 & - & 33.33 & 50.00 \\
AEM $1000 \mathrm{mg} / \mathrm{kg}$ & - & 16.66 & 16.66 & 33.33 \\
\hline
\end{tabular}

Untreated control indicates the group of animals receiving distilled water, and non-infected by $P$. multocida. Negative control represents the group of animals receiving distilled water but infected by $P$. multocida. Positive control indicates the group of animals infected by P. multocida and receives levamisole. Each group has 6 mice and the data represent the percentage of dead animal 


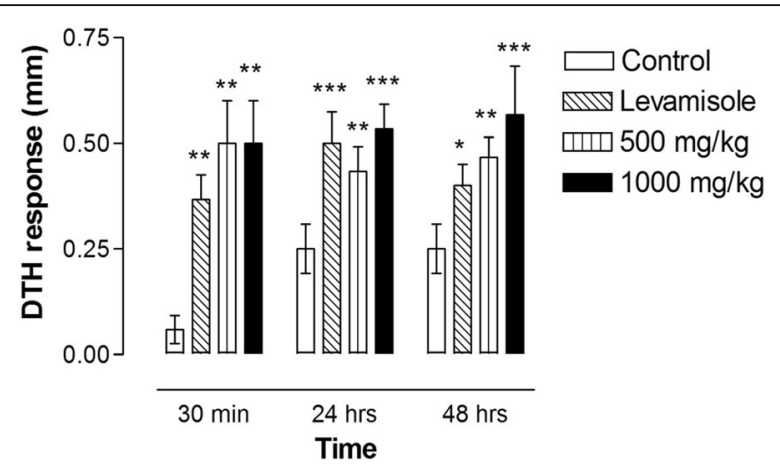

Fig. 1 Effect of T. clypeatus on DTH response using CRBC as an antigen in mice. Histogram represent Means \pm SD $(n=5)$. Means with signs*,*** and ${ }^{* * *}$ superscripts are significantly different as compared to dexamethasone control at the level of $0.05(p<0.05)$

\section{Discussion}

Many medicinal mushrooms are used to treat various specific health problems $[13,16]$. As can be seen in Table 2, the extract of $T$. clypeatus showed activity on the other test microorganisms $(2.5-10.5 \mathrm{~mm})$. The result of this study on the antimicrobial activity of $T$. clypeatus showed activity against $S$. aureus, E. coli and S. thyphimurium, E. aerogenes, C. albicans and C. glabrata at different ratios. This may be indicative of the use of $T$. clypeatus in treatment of several infections. The significant difference in the size of inhibition between the microbial species could have arisen from the dissimilar biochemical pathways utilized by the pathogen [17].

Modulation of immune responses to alleviate infectious diseases has been of interest for many years. [18] One of the major immune response associated with the elimination of bacteria and fungi is the humoral response. Antibodies function as the effectors of the humoral response by binding to antigen and neutralizing

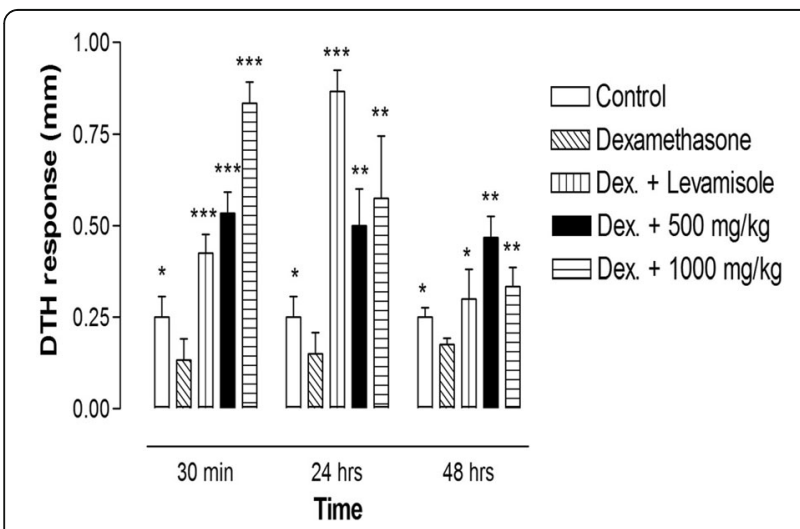

Fig. 2 Effect of $T$. clypeatus extract on DTH response using CRBC in Dexamethasone treated mice. Histogram represent Means \pm SD $(n=5)$. Means with signs*, ${ }^{* *}$ and ${ }^{* * *}$ superscripts are significantly different as compared to dexamethasone control at the level of $0.05(p<0.05)$ it or facilitating its elimination by cross-linking to form clusters that are more readily ingested by phagocytic cells $[19,20]$. The results of the study of the effect of $T$. clypeatus on antibody production are depicted in Table 3. The results showed that the extract increased dose-dependently the antibody titer in treated mice groups, but up $1000 \mathrm{mg} / \mathrm{kg}$ no significant difference has been observed when compared to untreated control (distilled water). In contrast, the extract has significantly reversed the inhibitory effect of dexamethasone. Despite the fact that the increase in production of antibody is not significant, the results indicate that the extract may stimulate the secretion of antibodies. This can be a result of the stimulatory activity of $T$. clypeatus on the secretion of antibodies by activated plasma cells or on the secretion of cytokines such as IL-4 from activated T lymphocyte cells [21]. Thus, this effect may be justify the reversion of the inhibitory effect of dexamethasone by the extract. Dexamethasone + levamisole group showed significant increase in HA titer as compared to dexamethasone + distilled water control group. This is evident since levamisole is known to restore corticosteroid induced depletion of immune response. Therefore, the extract may be had similar activity. An increase in production of antibodies may be an evidence of the importance of this mushroom demonstrated by the low mortality rate seen in $T$. clypeatus treated mice infected by P. multocida compared to control untreated.

The skin thickness increase was lower in the dexamethasone group when compared to the control. When compared to control, $T$. clypeaus and levamisole showed significant increase in skin thickness. Also, when compared to dexamethasone, Dexamethasone $+T$. clypeatus, Dexamethasone + levamisole showed significant increase in skin thickness. It has been demonstrated that DTH response results from the action of sensitized $\mathrm{T}$ lymphocytes, when challenged by antigen and were secrete a variety of molecules including proinflammatory lymphokines attracting more scavenger cells to the site of reaction [22]. Increased DTH response in treated animal showed that $T$. clypeatus might has a stimulatory effect on the lymphocytes and accessory cell types required for the expression of this reaction. A stimulatory activity on lymphocytes can boost phagocytic activity and increase concentration of lytic enzymes for more effective killing, which ultimately results in increase footpad thickness in immunized animals [23]. This suggests that T. clypeatus could enhance $\mathrm{T}$ cells proliferation and expression of the adhesion molecules, thus increasing migration of $\mathrm{T}$ cells to the site of inflammation.

Body weights of mice in treated groups decreased from the control or the dexamethasone groups indicating that the consumption of $T$. clypeatus has changed body weight of animals during the period of the study. 
Table 5 Effect of extract and levamisole on body weight in mice

\begin{tabular}{|c|c|c|c|c|}
\hline \multicolumn{5}{|c|}{ a. Effect on body weight in normal mice } \\
\hline Periods & Control & Levamisole & AEM $500 \mathrm{mg} / \mathrm{kg}$ & AEM $1000 \mathrm{mg} / \mathrm{kg}$ \\
\hline T0 & $18,65 \pm 1,51^{\mathrm{a}}$ & $17,42 \pm 2,46^{\mathrm{a}}$ & $19,6 \pm 2,80^{a}$ & $20,62 \pm 2,68^{a}$ \\
\hline T1 & $21,35 \pm 1,56^{\mathrm{a}}$ & $20,72 \pm 2,60^{a}$ & $16,22 \pm 1,94^{b}$ & $17,12 \pm 2,19^{b}$ \\
\hline RWG (\%) & $14.47^{\#}$ & $18.94^{\&}$ & $-17.24^{\xi}$ & $-16.97^{\delta}$ \\
\hline \multicolumn{5}{|c|}{ b. Effect on body weight in mice with dexamethasone induced immunosuppression } \\
\hline & Dexam. & Dexam. + Lev. & Dex.+ $500 \mathrm{mg} / \mathrm{kg}$ & Dex. $+1000 \mathrm{mg} / \mathrm{kg}$ \\
\hline T0 & $18,6 \pm 4,22^{\mathrm{a}}$ & $18,87 \pm 1,84^{a}$ & $18,97 \pm 1,32^{\mathrm{a}}$ & $17,07 \pm 2,50^{a}$ \\
\hline $\mathrm{T} 1$ & $19,95 \pm 4,33^{a}$ & $21,57 \pm 1,87^{a}$ & $16,52 \pm 1,23^{a}$ & $14,37 \pm 2,25^{b}$ \\
\hline RWG (\%) & $7.25^{\#}$ & $14.30^{\&}$ & $-18.91^{\xi}$ & $-15.81^{\varepsilon}$ \\
\hline
\end{tabular}

TO before treatment, $T 1$ after treatment, RWG relative weight gain at the end of period of the treatment. Data represent Means \pm SD ( $n=5$ ). Values with different letter $(a, b)$ superscripts, along column, are significantly different at the level of $0.05(p<0.05)$. Values with different symbol (\#, \&, ६) superscripts, along row, are significantly different at the level of $0.05(p<0.05)$

Mushrooms and mushroom-derived polysaccharides, have been shown to have therapeutic properties against metabolic syndrome, which is characterized by obesity, hyperglycemia associated with diabetes, hypercholesterolemia, and hypertension [24-26]. This was attributed to their anti-hypercholesteremic effects which result in body weight. Hence the decreased in body weight by the result may be a result of the effect of $T$. clypeatus on lipid mass. As low lipid mass could not be affect significantly the production of antibodies or cell proliferation, this could be justify the improvement of immune response by the extract while it lowers the body weight. $T$. clypeatus is an edible mushroom, largely consume without adverse effects. Hence, the decreased in the body weight observed could not be compromised its use for its immunomodulatory. Otherwise, T. clypeatus was administered through oral route in two form as additive aliment (powder) and dissolved in water (extract). As the powder was used in crude form this could be lowered the animal's appetite which can also result in loss of body weight.

\section{Conclusion}

The data suggest that T. clypeatus possesses immunostimulantory activity which is evident by increasing the cell-mediated and humoral immunity. This is demonstrated by stimulation of DTH response and haemagglutination (HA) titer in mice. T. clypeatus also showed antimicrobial activity that in addition to its immunostimulatory activity can be justified its exploitation in treatment of the infectious diseases. However, there is need to carry further study to establish the bioactives compounds of $T$. clypeatus as antimicrobials and immunostimulants.

\section{Acknowledgments}

The Authors are grateful to Dr. Salah Marin, Head of Department of Animal Production, University of Bamenda, Cameroon for providing the necessary laboratory facilities.
Ethical approval and consent to participate

Not applicable

\section{Authors' contributions}

OM: Concepts, Design, Experimental Studies, Data acquisition and Analysis, Manuscript preparation, Statistical Analysis. NAL: Collection and identification of species. AAM: Data acquisition. KA: Design and Analysis. All authors read and approved the final manuscript.

\section{Authors' information}

OUMAR Mahamat is a senior Lecturer, speciality Physiology/lmmunology, in the Department of biological Sciences, Faculty of Science, University of Bamenda. NJOUONKOU Andre-Ledoux is a senior Lecturer, speciality Botany/ Mycology, in the Department of biological Sciences, Faculty of Science, University of Bamenda. TUME Christopher is an Associate Professor, speciality Clinical Biochemisry, in the Department of Biochemistry, Faculty of Science, Univeisity of Dschang. ABAMUKONG Adeline Mbifu is a student in the Department of biological Sciences, Faculty of Science, University of Bamenda. KAMANYI Albert is a Professor, speciality Physiology, in the Department of Animal Biology, Faculty of Science, Univeisity of Dschang.

Consent for publication

All authors read and approved the final manuscript.

\section{Competing interests}

The authors wish to state that there are no competing interests associated with this publication and there has been no significant financial support for this work that could have influenced its outcome.

\section{Publisher's Note}

Springer Nature remains neutral with regard to jurisdictional claims in published maps and institutional affiliations.

\section{Author details}

${ }^{1}$ Department of Biological Sciences, Faculty of Science, University of Bamenda, PO. Box: 39, Bambili, Cameroon. '2Department of Biochemistry, Faculty of Science, University of Dschang, PO. Box: 67, Dschang, Cameroon. ${ }^{3}$ Department of Animal Biology, Faculty of Science, University of Dschang, PO. Box: 67, Dschang, Cameroon.

Received: 21 September 2017 Accepted: 1 October 2018

Published online: 27 November 2018

\section{References}

1. Fong $\mathrm{HH}$. Integration of herbal medicine into modern practices: issues and prospects. Integr Cancer Ther. 2002;1(3):287-93.

2. Ghorai S, Bamik SP, Verma D, Chowdhury S, Mukherjee S, Khowala S. Fungal biotechnology in food and feed processing. Food Res Int. 2009;42:577-87. 
3. Chu KK, Ho SS, Chow AH. Coriolus versicolor : a medicinal mushroom with promising immunotherapeutical values. J Clin Pharmacol. 2002;42:976-84.

4. Reimer LG, Wilson ML, Weinstein MP. Update on detection of bacteremia and fungemia. Clin Microbiol Rev. 1997;10:444-65.

5. Jafarian A, Zolfaghari B, Parnianifard M. The effects of methanolic, chloroform and ethylacetate extracts of the Curcurbita pepo L. on the delayed type hypersensitivity and antibody production. Res Pharm Sci. 2012; 7(4):217-24.

6. Paul NW, Eliud MG, Benson MG, Keziah MO. Antimicrobial activity of mushroom (Agaricus Bisporus) and fungal (Trametes Gibbosa) extracts from mushrooms and Fungi of Egerton Main campus, Njoro Kenya. J Biomed Sc. 2017:6(3:19):1-6.

7. Thillaimaharan KA, Sharmila K, Thangaraju T, Karthick M, Kalaiselvam M. Studies on antimicrobial and antioxidant properties of oyster mushroom Pleurotusflorida. Int J Pharma Sci Res. 2016:4:1540-5.

8. Njouonkou AL, De Crop E, Mbenmoun MA, Kinge TR, Biyé EH, Verbeken A. Diversity of edible and medicinal mushrooms used in the noun division of the west region of Cameroon. Int J Med Mushrooms. 2016;18(5):387-96.

9. De Casro MEG, Dulay RMR, Eneiquez MLD, et al. Toxic and teratogenic effects of medicinal and culinary mushroom, Termitomyces clypeatus, collected from the termite mound in Mt. Makiling Forest reserve, Los Baños, Laguna, Philippines on developing embryos of zebrafish (Danio rerio). Pharm Lett. 2016;8(5):237-42.

10. Ghate SD, Kandikere R. S. Bioactive potential of Lentinus squarrosulus and Termitomyces clypeatus from the southwestern region of India. IJNPR. 2017; 8(2):120-31.

11. Jyoti PT, Koichi W, Wilhelm H. Diversity of microorganisms in global fermented foods and beverages. Front Microbiol. 2016;7:377.

12. Heden CG. On the estimation of fifty percent end-points in serological titrimetry. J Pathol Bacteriol. 1946;58:477-81.

13. Shabbir A, Arshad HM, Shahzad M, Shamsi S, Ashraf MI. Immunomodulatory activity of mefenamic acid in mice models of cell-mediated and humoral immunity. Indian J Pharmacol. 2016;48(2):172-8.

14. Cleven BEE, Palka-Santini M, JörgGielen SM, Krönke M, Krut O. Identification and characterization of bacterial pathogens causing bloodstream infections by DNA microarray. J Clin Microbiol. 2006;44(7):2389-97.

15. Paula CBW, Orlando CM, de Paula A, VPA V, ADFA P, Jackelline RA, CGA S, CCB M. New susceptibility breakpoints in antimicrobial resistance rates of invasive pneumococcal strains. J Pediatr. 2009;85(5):421-5.

16. Tsungai R, Chenjerayi K, Catherine C, Mudadi AB, Takafira M. Antibacterial properties of wild edible and non-edible mushrooms found in Zimbabwe. Afr J Microbiol Res. 2016:977-84.

17. Roy DN, Azad AK, Sultana F, Anisuzzaman AS. In-vitro antimicrobial activity of ethyl acetate extract of two common edible mushrooms. Aust J Pharm. 2016:5:79-82.

18. Ranganathan V, Selvasubramanian S. Evaluation of cell mediated immune response in rabbits fed with Cucurbita maxima seeds. Indian J Anim Res. 2015;49(2):223-6.

19. Cristiane UJ, Eliana F, Margô GO, Karnikowski JK. Antimicrobial properties of the mushroom Agaricusblazei - integrative review. Braz J Pharmacog. 2016; 26:780-6.

20. Brinc D, Le-Tien H, Crow AR, Siragam V, Freedman J, Lazarus AH. Transfusion of lgG-opsonized foreign red blood cells mediates reduction of antigenspecific B cell priming in a murine model. J Immunol. 2008;181(2):948-53.

21. Anarthe SJ, Malavika E, Pravalika A, Ganga R M. Screening of immunomodulatory activity of Sphaeranthusindicus Linn. whole plant. IOSRJPBS. 2015;10(6):91-9.

22. Dannenberg AM Jr. Roles of cytotoxic delayed-type hypersensitivity and macrophage-activating cell-mediated immunity in the pathogenesis of tuberculosis. Immunobiology. 1994;191:461-73.

23. Kobayashi K, Kaneda K, Kasama T. Immunopathogenesis of delayed-type hypersensitivity. Microsc Res Tech. 2001;53:241-5.

24. Kundakovi'c T, Kolundži'c M. Therapeutic properties of mushrooms in managing adverse effects in the metabolic syndrome. Curr Top Med Chem. 2013;13:2734-44

25. Wasser SP. Medicinal mushroom science: current perspectives, advances, evidences, and challenges. Biom J. 2014;37:345-56.

26. Su CH, Lai MN, Lin CC, Ng LT. Comparative characterization of physicochemical properties andbioactivities of polysaccharides from selected medicinal mushrooms. Appl Microbiol Biotechnol. 2016;100: 4385-93.

\section{Submit your manuscript to a SpringerOpen ${ }^{\circ}$ journal and benefit from:}

- Convenient online submission

- Rigorous peer review

- Open access: articles freely available online

- High visibility within the field

- Retaining the copyright to your article

Submit your next manuscript at $\boldsymbol{\nabla}$ springeropen.com 